\title{
Matariki 2010
}

\author{
Ka puta Matariki ka rere Whānui. Ko te tohu teenaa o \\ te tau e!
}

Matariki re-appears, Whānui starts its flight. Being the sign of the [new] year!

Ko Matariki te tino tau hou o Aotearoa, o te Moananui-aKiwa. E ahu mai ana toona ingoa i te kaahui whetuu o Matariki; e whitu ngaa whetu o te kaahui nei, aa, hei ngaa wiki whakamutunga o Haratua, ngaa wiki tiimatanga o Pipiri raanei ia tau, ia tau ka puta ake anoo. Ko toona ingoa $i$ te ao maatauranga taatai arorangi Paakehaa ko Pleiades.

I te tau 2010 ko te 14 o Pipiri te raa ka whakanuia a Matariki.

Matariki is our Aotearoa Pacific New Year. It takes its name from the seven star constellation which reappears over the horizon in late May. In Western astronomy this constellation is called The Pleiades.

In 2010 Matariki will be celebrated on June 14.

\section{http://www.korero.maori.nz/news/matariki}

Ka tiimata te waa o Matariki maaku i teetahi hiikoi, he haerenga tuuturu $i$ te rohe o Rangitaane, aa, ko Paaora Hortom te kaiaarahi. Ka tiimata maatou i Awapuni. Ki reira ka maatakitaki maatou i nga waahi o ngaa paa taawhito $i$ te whenua raupoo raa. Ko Awapuni, te waahi o Rangitaane Paa i teenei waa, he waahi tino nui ki a Rangitaane o Manawatu.

Matariki began for me with a Hikoi, a properly organized tour of the Rangitaane area with Paul Hortom the guide. We started in Awapuni. There we looked at old $\mathrm{Pa}$ sites in the 
lowland area. Awapuni, the site of the present day Rangitaane Paa was a very important area for Rangitaane o Manawatu.

Ka haere maatou ki Ashurst. I a Paaora e koorero ana moo Aapiti, teetahi anoo tino waahi moo Rangitaane, ka puta mai he kereruu ki teetahi raakau tata ki te tiro noa $i$ nga whakahaerenga. He waa miiharo teenaa.

We went to Ashurst. While Paul was telling us about Apiti, another important place for Rangitaane, a kereru came into a nearby tree and observed proceedings. It was a magical time.

Ka haere maatou ki ngaa uru karaka e tata ana ki te whare waananga. He waahi marino, taumaha hoki. Ki reira ka kite maatou i eetahi kai peenaa i teenaa i te Ahurei Kai Tuawhenua o Rangitaane $i$ whai ai.

We went to the karaka groves near the university. A quiet, serious place. There we saw some kai the likes of which would be used in the forthcoming Rangitaane Wildfood Festival.

Ki tua o teenaa ka haere te ope ki te tapawhaa, te Marae o Hine, aa, ka noho maatou $i$ te taha o ngaa whakairo ki te whakarongo ki a Paaora me eetahi atu taangata tae noa ki nga kaumatua $i$ puta ai i a raatou e koorerorero tonu ana moo Rangitaane.

Then it was to the square where we sat beside statues and listened to Paul and others including the elders in attendance telling us more about Rangitaane.

Araa, kia taea teetahi kotiti noa, a, kia rongohia ai he koorero rahi na Paaora me nga mea i tautoko ai i a ia ka hoki maatou ki te kaainga, ki a Awapuni.

And then, after a bit of a wander, taking in a lot of information from Paul and others who contributed we came back to base, to Awapuni. 
I teenaa poo ka noho maatou ki Tuuturu Puumau, te wharenui ki Rangitaane Paa i Awapuni. Ka whakamaatau maatou $i$ te mahi waka ama ki roto $i$ te whare $i$ a matou $e$ whakatika ana $i$ a matou anoo moo te haerenga maa runga waka $i$ Tangimoana $i$ te raa $i$ whai ai.

That night we all stayed at Tuturu Pumau the meeting house at Rangitaane $\mathrm{Pa}$, Awapuni. We practiced waka ama work indoors getting ready for an expedition or an exercise on a waka at Tangimoana the next day.

I te tino ata o te raa $i$ whai ai ka taea te kawa o Matariki i mua $i$ te haapaitanga o te haangi. Ka whai mai teetahi rauna tapu o te koorero $i$ roto $i$ a Tuuturu Puumau. A, kia taea ai te haapaitanga o te haangi, ko te parakuihi. He reka rawa atu teenaa!

Then there was the predawn ceremony welcoming in Matariki before the haangi was lifted. And then a round of korero. And then, the haangi lifted, breakfast. It was delicious.

Ko te mea i whai mai i tooku wa Matariki ko te konohete o nga Tuahine Tokowhitu ki Te Papa Tongarewa i te Whanganui a Tara. Kiikii rawa atu te wahi marae $i$ te reanga teitei $o$ te whare taonga moo teenei. He rahi ngaa waiata $i$ tito ai i nga kaiwaiata, aa, he tino pai te haanga o eenei waiata. He raarangi kaiwaiata atu i a Lisa Tomlin ki a Ria Hall. Ko Puawai Cairns i te rakuraku te mea tautoko i a Ria, aa, ko oo Puawai kakahu, he neketai maa i runga $i$ te hate pango. Atu $i$ te pai o toona aahua he hoa tino pai a Puawai moo Ria, te tangata ngaawhaariki rawa o te poo. Ko taa raaua te mea tino pai rawa pea ki te minenga.

http://www.youtube.com/watch?v=w6Hhomgzz3M\&featur $\underline{\mathrm{e}=\text { related }}$

My next Matariki experience was the Seven Sisters concert at Te Papa Tongarewa in Wellington. The marae area on the top floor of the museum was packed out for this. Many of the songs were originals and they were well constructed. There was a range of singers from Lisa Tomlin to Ria Hall. Puawai 
Cairns backed Ria on guitar wearing a white tie on a black shirt. As well as looking great Cairns made a great foil for the effervescent Hall.

Theirs seemed to be the most popular set.

He tino pai a Kali Kopae $i$ aana waiata, a, ka tautokongia ia e James McGaskill. He tino pai hoki a Bella Kalolo, aa, he piano hau i muri i a ia. Kia whakaarongia a Ramon Tewake me te kaiwhakahaere o te poo, he tino pai te katoa o teenei whakaaturanga.

Kali Kopae impressed with her set backed by Jamie McCaskill on bass. Bella Kalolo was also impressive with an organist behind her vocal. With Ramon Tewake and the compere considered this was a very even display of high quality.

He tino pai hoki te whiringa aa rohe o nga kaiwaiata. Ko Lisa Tomlins raaua ko Bella Kalolo, ka puta mai raaua mai $i$ te Whaanganui a Tara, aa, ka kitea ngaa waiata reka rawa, torutoru rawa hoki ki reira, a, i teenaa rohe ko te waiata teetahi ira noa i te kaakahu. Ko eetahi kaiwaiata ka puta mai raatou i te kura kaiwaiata-kaituhi, a, ki reira ko te kaiwaiata te tiimatatanga me te otinga 0 te whakaaturanga. Ka hari a Kali Kopae i ngaa aahua hou me toona anoo reo waiata e whai rarangi ana. Engari he rawe te pai o aa Lisa Tomlins waiata. Ko toona, he reo korero e tata pakeke ana.

The performers at Seven Sisters were well selected on a geographical basis as well. Lisa Tomlins and Bella Kalolo come out of a Wellington environment where the music is sophisticated and the vocal is one thread in the cloak. Other singers were from the singer-songwriter school where the singer is the beginning and end of the performance. Kali Kopae brought a freshness to things with a voice that had range and originality but there was no mistaking the quality of Lisa Tomlins' work. Hers is a voice finding maturity. 
Kaaore he paatai moo nga mahi waiata motuhake e kitea raa ki te Whaanganui a Tara. Ka kite anoo au i a Lisa Tomlin $i$ te minenga $o$ te Wellington Blues Club ki te Bristol Tavern ki te huarahi o Cuba, aa, ko te whakaaturanga o te poo ko te mahi rakuraku tino pai rawa atu a Dougal Spiers me te reo waiata o Julie Lamb. Ko taa Lisa, wheenaa i ngaa mea o te ao waiata $i$ te Whaanganui a Tara- te titiro, te whakarongo, te ako hoki, raatou $i$ a raatou anoo.

\section{http://www.youtube.com/watch?v=r7VPbZy4Lpg}

There seems no question about a distinct musical culture in Wellington. I next saw Lisa Tomlins in the audience at the Wellington Blues Club at the Bristol Tavern in Cuba Street at a show featuring the fine guitar of Dougal Spiers and the vocal of Julie Lamb. She was doing what musicians and vocalists do a lot of in Wellington- looking listening and learning off one another.

Ko Kali Kopae, ko teenaa taaku whiringa pai rawa atu. He reo waiata tika, ngaawari hoki ki te taringa, aa, ko ngaa waiata peenaa i a Drive, he rawe hoki. He tawhiti kee te hiikoi o teenei kaiwaiata mai i toona waa ki NZ Idol, aa, ka kuukune te whakaaro moona kia whakaarongia ai taa Kali mahi e whai mai.

http://www.youtube.com/watch?v=v3J83HEpAyU\&featur $\underline{\mathrm{e}=\text { related }}$

Kali Kopae was, in fact, my favourite. The voice was real and easy to listen to and the songs like Drive were well done. This singer has come a fair way since her NZ Idol days and there is an excitement now about what Kali will do next.

Ko te tokorua naa, a Ria Hall me Puawai Cairns i runga rakuraku, he aahua hooro waiata $i$ taa raua, a, he kaha raa a Ria ki te waiata, he paa pai taa Puawai i te rakuraku. Ka whakangahau raaua $i$ te minenga. Wheenaa hoki raa aa 
Ramon Te Wake, he rongo katakata $\mathrm{i}$ aana kupu waiata. Ka whakaatu a Bella Kalolo i toona anoo kaha.

http://www.youtube.com/watch?v=3GKOpOABJsU\&featur $\underline{\mathrm{e}=\text { related }}$

Ria Hall and with Puawai Cairns on guitar offered a music hall feel as well as power on vocal and a touch on the guitar. They entertained. So did Ramon Te Wake with a sense of humour in her really droll and interesting lyrics. Bella Kalolo showed her power.

\section{http://www.youtube.com/watch?v=v0zZqivdPd4}

Ko te mea whakatepe, he mea tino pai teenaa, aa, ko te waiata i meatia e te katoa ko Maranga ake ra.

http://www.youtube.com/watch?v=0vh$\underline{\text { tGolbbU\&feature }=\text { related }}$

The finale was well done with Maranga ake mai as the shared song.

Ka whakaahuatia te nuinga o nga kaitapere, aa, ka kitea eenei $i$ te ipurangi.

Most of the performers were filmed and may be found on the internet.

Ko te mea whai ake i tooku waa Matariki ko Koowhiti; Matariki Festival of Contemporary Dance i whakatuungia ai i Hune 24-27 ki te Papa Tongarewa anoo.

The next thing I attended during Matariki was Koowhiti; Matariki Festival of Contemporary Dance held June 2427/2010 again at the Museum of New Zealand, Te Papa Tongarewa. 
Ko te waa tapere o nga waa tapere teenei. He whakaaturanga kanikani tuuturu, he kanikani Maaori, ki Te Papa Tongarewa. Ko teetahi mea nui ko te haakari ki Icon, te waahi kai ki te papa Tongarewa. He mea hirahira inahoki he rahi ngaa taangata rongonui i puta ai. He mema tuakana mai i te Paremata, he kaiwhakawaa o te Kooti Teitei, ki reira hoki ko Kerry Prendergast te Koromatua o te Whaanganui a Tara, eetahi atu mema paremata, roia hoki.

It was the show of shows. A comprehensive display of dance, Maori dance at Te Papa. It featured a Hakari, a Dinner at Icon the dining complex at Te Papa Tongarewa and this was remarkable for the dignitaries there. Senior politicians, High Court judges, Kerry Prendergast, the Mayor of Wellington, sundry MPs and lawyers.

Ko Brendon Pongia mai $i$ te pouwhakaata $o$ te ata te kaiwhakahaere moo te haakari, aa, ka whakahoki ia i a maatou katoa ki te whenua tonu i eetahi koorerorero moo Dancing with the stars. He koa kee au ki te whakatuu i tooku ringa $i$ taa Brendon paatai ko wai $i$ maatakitaki $i$ Dancing with the stars. Kaaore he koorero ahiahi teenei. Ka moohiotia te minenga $i$ teenei paatai. Ko teenei he hui o ngaa taangata matatau i nga tihi o te ao toi. He itiiti kee raa ngaa kaupoi, ngaa mea kuuare wheenei i a au. Engari he tino tangata a Brendon moo ngaa mahi peenei, he kaikanikani, he kaitaakaro hoki ia, aa, ka whakauru ia i a Toni Huata moo eetahi waiata kaha, aa, ka whakatikatika hokitia te minenga e ia moo Koowhiti tonu me te hoatutanga tohu ki te whai mai.

Brendon Pongia of morning television was the Master of Ceremonies for the meal and he got us all down to earth with a lot of patter about Dancing with the stars. I was proud to put my hand up when Brendon asked who watched Dancing with the stars. This was not idle chatter. This sorted the audience out. Here was an audience of Welllington High Culture. Lowbrows like me were in the distinct minority. But Brendon was the perfect foil, dancer and sportsman, introducing Toni 
Huata for some powerful waiata and getting everyone ready for the show itself, Koowhiti and the presentation of awards to follow.

Araa, kua whakatereteretia te minenga e MC Pongia i a maatou e kai puurini ana, ka nekeneke maatou $i$ te hooro kai ki teetahi o nga hooro tapere i Te Papa moo te waa tapere.

And then, with a bit of a hurry-up from MC Pongia over the dessert, we all moved from the banquet room to a theatre at Te Papa for the show.

Ko te kaupapa o te kupu koowhiti ko te whiriwhri, te too ake ranei. Ka taea te koorero; 'kua koowhiti nga kuumara.' Ko tetahi atu kaupapa ko te putahanga mai o te maarama hoou, a, ko teetahi aahua koorero o teenei ko te whakaruahanga o te whiti hei koowhitiwhiti. Ka aro teenei ki te pekepeke, te kanikani raanei o te wai.

Koowhiti means to pull out or to select. It can be used to say something like, 'the kumara were pulled out of the garden'. It also has the secondary meaning of the appearance of a new moon and there is an interesting usage with a replication of whiti in koowhitiwhiti which refers to a leaping or dancing of water.

Engari raa ko te kaupapa o Koowhiti moo nga mea i puta ake raa ki te whakaaturanga nei, ngaa whakaaturanga kanikani raanei ki Te Papa Tongarewa i te waa o Matariki. Ko eetahi o eenei, he mea mai i eetahi whakaaturanga o mua, ko eetahi, he mea hoou. He mea tino tata $i$ waaenganui o eenei whakaaturanga, he mea rerekee hoki. Araa, ko Koowhiti, he kohinga whakaaturanga i nukunuku ai wheenaa i te wai i te waihiirere (cf Ka'ai Mahuta 2009).

But Koowhiti, for those who attended will always mean the performance or a set of dance performances at Te Papa Tongarewa during Te Matariki. Some of these were excerpts from earlier shows and others were new shows. There were 
strong similarities amongst the shows and there were differences as well. Koowhiti then was a set of shows shifting in shape like dancing water in a fountain (cf Ka'ai Mahuta 2009).

Kaaore he wera $i$ te rae moo te mahi ahurewa $i$ taea ai e Cathy Knowsley me taana roopu. He rawe hoki te mahi whakamaarama naa Lisa Maule. He peenaa te katoa o eenei mahi $i$ te rerenga o te karaka, aa, peenaa raa eenei mahi moo te pai o te pourewa ki te kai i te haakari, he mea aataahua ki te whatu, he mea pai maa te puku hoki.

Stage management was well done without fuss or fanfare by Cathy Knowsley and her crew. Lisa Maule provided very effective lighting. It all ran like clockwork and like the food at the hakari it was both elegant and sustaining as background for the performances.

Ko Cat Ruka he tangata tuu atu. Ka tuutaki te waahi kanikani ki te waahi tapere; ka mea ia pikitia kanikani i taana anoo koorero me kii, aa, i eetahi aahuatanga ko Cat te mea tino pai rawa o ngaa taangata katoa $i$ puta ai ahakoa kaaore kau he rahi te kanikani i taana. Kaaore he haate $i$ a ia, he tapere takitahi taana, a, he mea tautoko i eetahi mea mai $i$ te ao o te wahine Maaori, he wahine e taawhititia ana. I a au e matakitaki ana i a Cat ka whakaaro au mo ngaa tuhinga naa Cheryl Te Waerea Smith moo ngaa mea e mauhere ana $i$ te iwi Maori (cf Smith 1993). I taa Cat Ruka ka kitea te taawhiti o te wahine Maaori i nga hikareti, I te waipiro me ngaa taru kino. Ka hiinaki hokitia te wahine raa e nga keengi, e nga turuhi hoki pea- ka hari noa raa a Cat $i$ teetahi karetao $i$ a ia $e$ tapere ana. Ka marutia, me kii, e teenaa haki, teenaa raanei. Ka taapareparetia ia $\mathrm{i}$ teetehi whare mamae. Ka rongohia eetahi aronga $o$ te taperetanga $o$ Beth mai $i$ te pukapuka me te pikitia, Once were warriors, aa, ka haria eenei aronga ki teetahi anoo reanga $i$ eetahi aahua (cf MacDonald 1995, Cleave 2009a). 
Cat Ruka stood out. Dance met theatre at Koowhiti; every dance-picture told a story and she was the best in many respects even though she did not dance much. Bare breasted, her solo dance involved props from the world of the Maori woman, a woman trapped. While I was watching Cat I thought of writing by Cheryl Te Waerea Smith about things that trap Maori people (Smith 1993). In Cat Ruka's work thr entrapment of the Maori woman by cigarettes, alcohol and drugs is to be seen. The woman is also trapped by gangs and also perhaps by tourists- Cat carries a doll as she performs. She is wrapped up in a house of pain. This echoed the role of Beth in the book and the film of Once were warriors and took it a stage further in some respects (cf Mac Donald 1995, Cleave 2009a).

Engari, he rahi kee nga mea i te waa tapere nei. Ko eetahi o ngaa kaikanikani he aahua koroheke raatou engari raa he rahi kee mai $i$ te rangatahi, aa, he mea hoou, tuuwhera hoki ki te whai $i$ te rangatiratanga 0 Taanemahuta raaua ko Merenia $i$ runga $i$ te ahurewa me te moohio tootika rawa. Ko te rangatahi, mai i nga kura o te Judith Fuge Dance Studio me te waa ako e kiia nei ko te Commercial Dance Course kei te Whare Tapere o Whitireia raatou.

But there was much else in the show. One or two of the dancers were older but a lot were younger and they came with an open freshness, taking the lead of Tanemahuta and Merenia on stage with very clear understanding. The young ones came mainly from the Judith Fuge Dance Studio and the Commercial Dance course at the Whitireia Performing Arts Centre.

Ka kitea te mahi a Taupuhi Toki me New Native Dance hei mea pai rawa i Paa Kingdom. Aa, ka haria te tono me te whakaaturanga e Cathy Livermore me te Atamira Dance Company ki eetahi reanga teitei i Don't feed the man fish. Ka ui hokitia eetahi paatai hoou moo ngaa mea peenaa i te whakamahanatanga $o$ te ao mai $i$ te tirohanga $o$ te iwi taketake. 


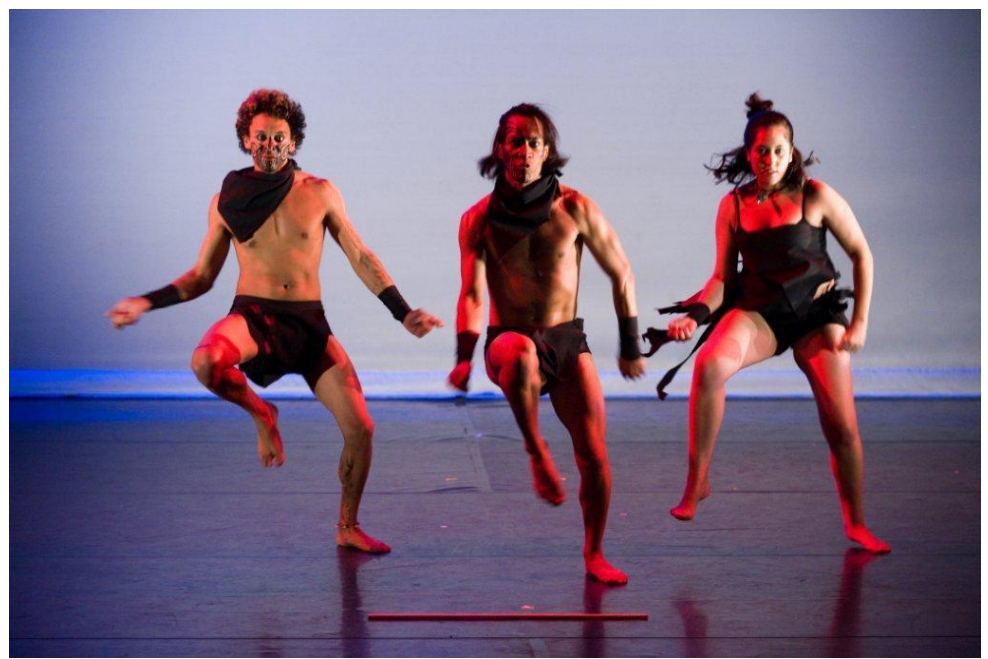

New Native Dance

Pā Kingdom

Choreography: Taupuhi Toki, New Native Dance Creative Producer: Kasina Campbell

Dancers: Jai Campbell, Andy Faioga, Ellen Moana Smith, Taupuhi Toki

The work of Taupuhi Toki and New Native Dance was seen to effect in Paa Kingdom. And the choreography of Cathy Livermore and the Atamira Dance Company in Don't feed the man fish took message and performance to new heights and asked new questions about things like global warming from the point of view of indigenous people.

Ka tautoko te New Zealand School of Dance i a Merenia Gray me te Merenia Gray Dance Company i Black Rain. Aapiti atu $i$ te kanikani pai he rawe hoki te waiata me nga koorero atu $i$ aa Hirini Melbourne raaua ko Richard Nunns ki teenaa naa Hone Tuwhare. 


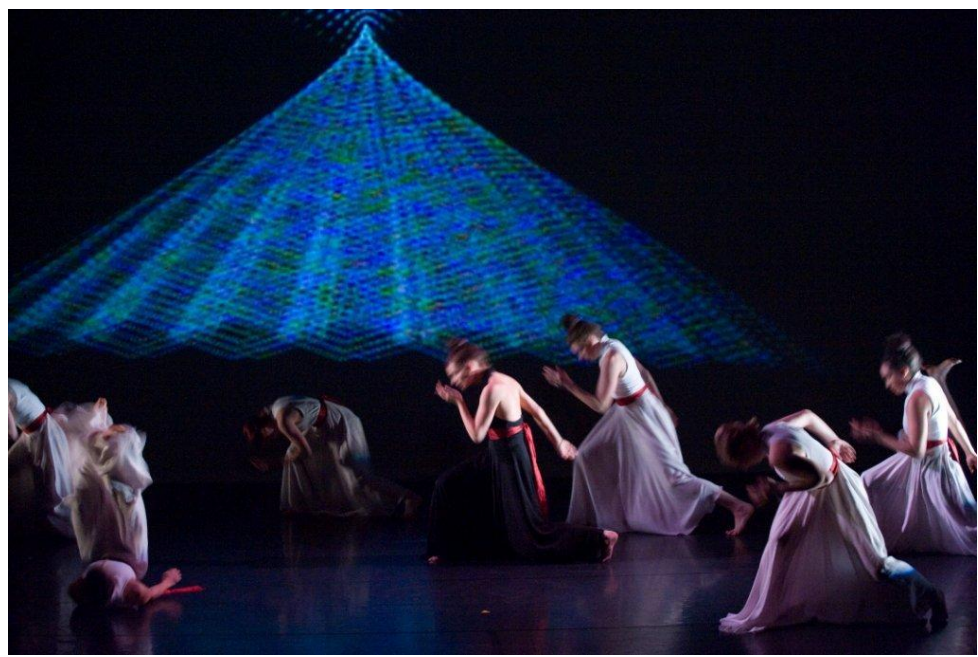

Black Rain -Merenia Gray Dance Theatre

The New Zealand School of Dance supported Merenia Gray and the Merenia Gray Dance Company in Black Rain. As well as the superb dance this show had an excellent use of music and poetry ranging from the work of Hirini Melbourne and Richard Nunns to that of Hone Tuwhare.

Kia piri a Taanemahuta Gray i te waa o naaianei inahoki ka rongohia nga waiata naa Tiki Taane $i$ Past/Present/Future me Tangaroa me This is it hoki. Ka whakauungia teenei aahua o naaianei e Future Fame. Ka tautokongia ia e Mad Fame Creative Specialists i The Inner Cosmos. Ka rongohia hoki he waiata naa Mr Flash me taa The Dorian Concept. 


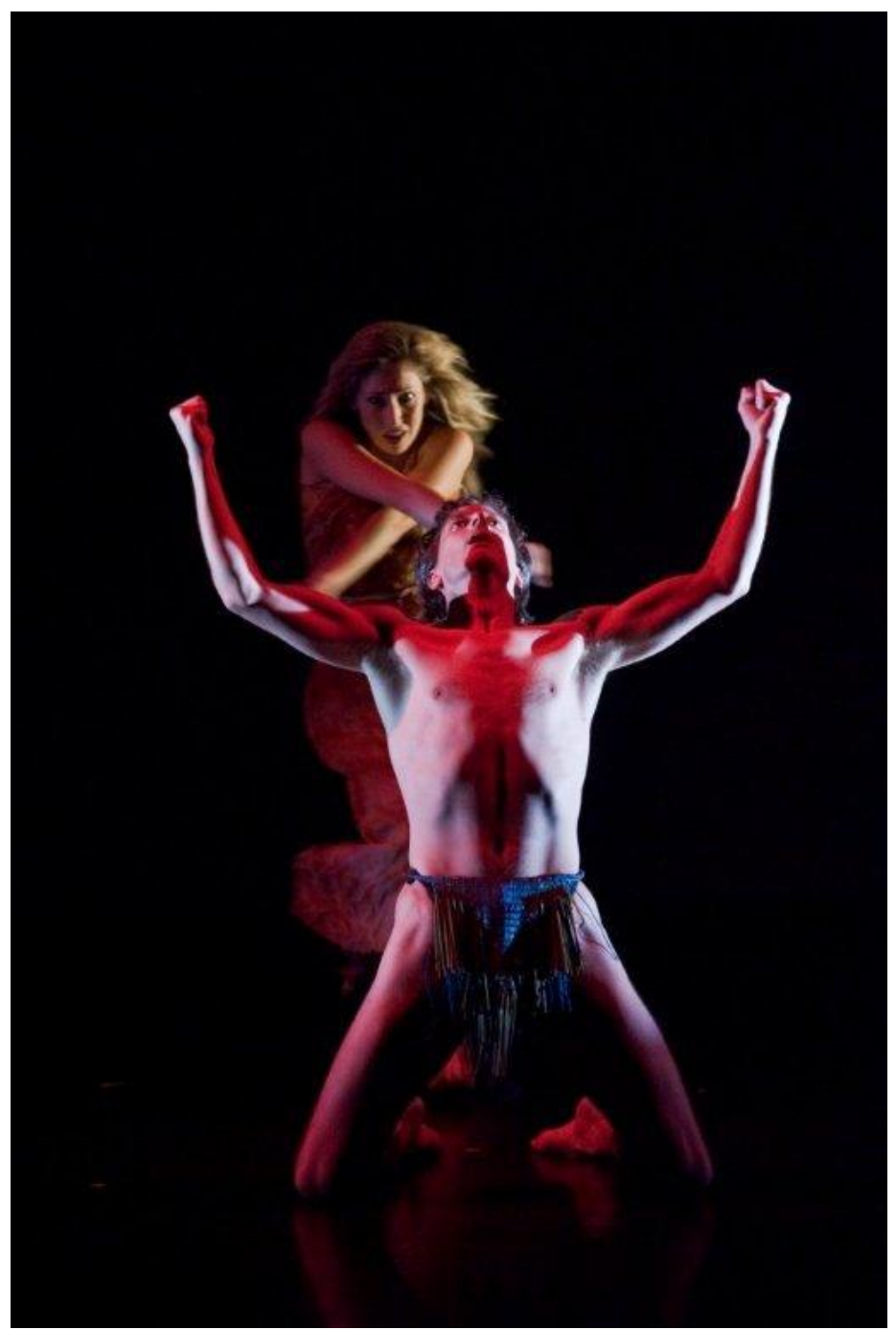

Past / Present / Future

Choreography: Tanemahuta Gray

Music: Tiki Taane - Past Present Future Album: Past / Present / Future Costume Design and Construction: Mina Davies, Olivia Giles, Moana Jones (Maro) Dancers: Jacqui Hailwood, Tanemahuta Gray 
Tanemahuta Gray used the music of Tiki Taane in his Past/Present/Future and in Tangaroa and Now this is it, keeping things current. The contemporary feel was reinforced by Future Fame appearing courtesy of Mad Fame Creative Specialists in The Inner Cosmos. This featured the music of $\mathrm{Mr}$ Flash and The Dorian Concept.

Ko Merenia Gray ka huri hoki ia ki nga koorero aataahua, araa, ki a Octavio Paz, ko The Sacred Fig Tree he puutake mo Entangled. Ka haangai, hookai hoki a Merenia ki eetahi mea, aa, kaaore i ngaro taana anoo ira. He paa pai kia miiharotia ai.

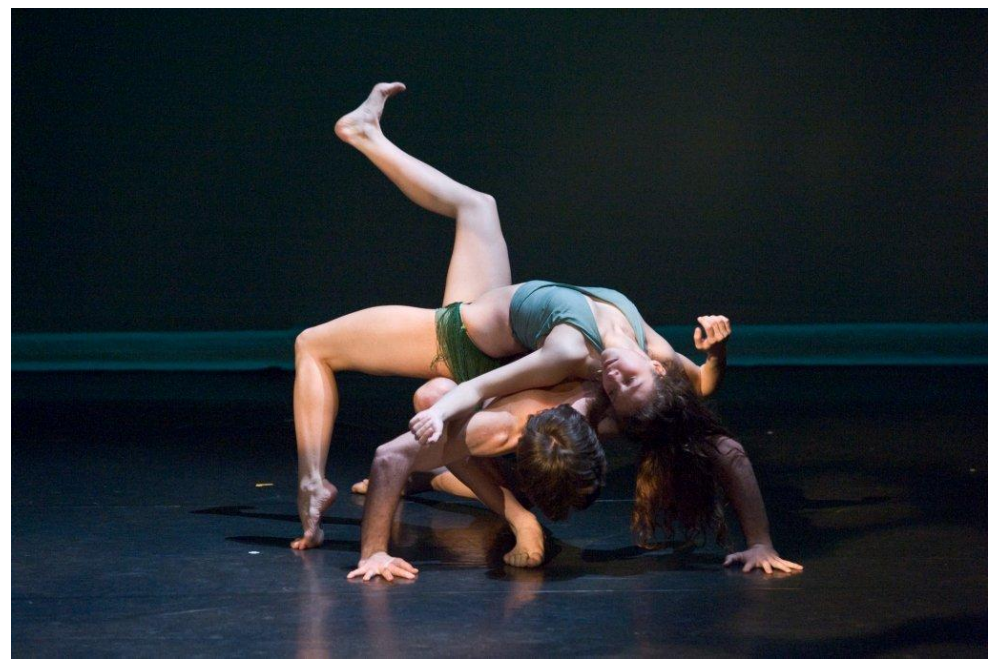

Entangled

Choreographer Merenia Gray - Dancers - Footnote Dance Company

Merenia Gray also used poetry in Entangled, this time taking Octavio Paz's The Sacred Fig Tree as an inspiration. Merenia cross referenced to a lot of things without losing the thread. A subtlety to be wondered at.

He tawhiti hoki te hokinga atu o eetahi mea. Mai i teetahi whakaaturanga i te tau 1990 ka puta mai He Taura 
Whakapapa me te mahere kanikani naa Charles Konehoneho me Te Toki Haruru. Ko teenei mahi, he kaupapa kei roto moo te uauahanga o te kotahitanga, aa, peenaa i eetahi mahi i teeraa poo ka noho noa eetahi paatai.

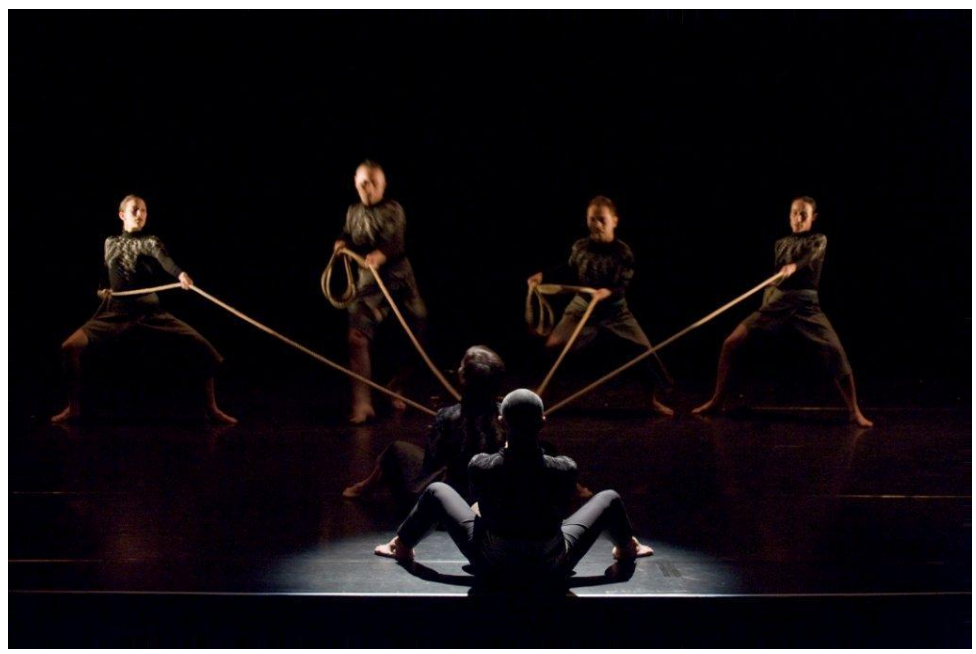

He Taura Whakapapa:

Choreography: Charles Koroneho, Te Toki Haruru Music: Marc Chesterman \& Grant Finlay: Ka puta he Kakano; (compiled by Te Toki Haruru) He Whakapapa: Ngahiwi Apanui Costume Design: Marama Llyod \& Charles Koroneho Dancers: Charles Koroneho / Tai Royal, Maaka Pepene, Jack Gray, Cathy Livermore, Gabby Thomas, Bianca Hyslop

Some of the work went back a fair way. He Taura Whakapapa with choreography by Charles Koroneho and Te Toki Haruru came from a production by the Taiao Dance Theatre in 1990. With a theme concerning the fragility of unity the work, like all other pieces on the night posed questions that lingered.

Ko eetahi o nga mahi aa roopu ka tuutaki pai ahakoa ngaa mea uaua, ngaa mea whakamataku. Ko te tautoko mai i a Kid Genius Klik moo Playing Savage naa Cat Ruka 
he mea miiharo teenaa hononga. Kei Playing Savage hoki nga waiata naa Chopin me Notorious BIG. Ka pai te hari o te whakaaturanga $i$ eenei rangi rerekee.

Some of the collaboration worked extremely well, taking all kinds of risks. The support of Kid Genius Klik for Cat Ruka's Playing Savage made for a magic combination. Playing Savage also employed the music of Chopin and Notorious BIG. The presentation carried the musical contrasts.

Ko te mahi i kitea ai i Te Koowhiti ka puta mai eetahi tino whakaaturanga $i$ ngaa waa o mua, aa, ka aata whakaarongia ngaa take kia kitea ai ngaa aahua o te Maori mai raanoo. Mai i te tau 2006, te tau o te hooia tawhito, te Year of the Veteran, ka puta nga whakaaturanga 0 Moonlight Sonata me Memoirs of Active Performance kia titiro whakamurihia ai te waa o te Maaori, tae rawa anoo raa ki ngaa mea mai $i$ te tuawhenua me ngaa waahi taawhiti, $i$ a raatou e hiikoikoi ana $i$ te mihini pakanga $o$ Niu Tiireni.

The way Koowhiti worked was that key performances from the past were selected with an eye on the message so that the experience of Maori over time was reflected. Moonlight Sonata and Memoirs of Active Service dating from 2006, the Year of the Veteran, looked back to the long experience of Maori, especially Maori from remote areas in the New Zealand war machine.

Ka hikitia te paatai moo ngaa mea taawhiti me ngaa mea tata, he whakarerekeetanga nui i ngaa whakaaetanga Tiriti inahoki raa ko te aahua he mea ngaawari te whakatau whakaaro te rapu taonga $\mathrm{ki}$ te whenua peenaa $i$ te hinu i nga moana me nga whenua taawhiti (Cleave 2009a). He mea nui te taawhiti i te moemoeaa kino o te taaone o Cat Ruka ki te oranga $i$ te tuawhenua me te oranga $i$ te waahi pakanga, aa, kua tuhi eetahi taangata moo teenei. Ko te mahi i tekaharoa.com naa Moon me Keiha (2008) te mea hoou rawa pea engari raa ka rere teetahi taatai whakaaro ki taa Laurence McDonald (1995 
ibid) moo te taha taane, wahine raanei e kitea ana ki te pukapuka me te pikitia Once were warriors. Ka pai a Beth ki te tuawhenua engari kaaore a Jake e pai ana ki teenaa. Ka whakaaro te tangata moo te koorero naa Ani Salmond (Salmond, 1975) moo ngaa waahi nunui o te tuawhenua peenaa i a Te Teko, Ruatoki raanei, aa, ka whakaarongia taa Joan Metge moo te haerenga ki te taaone (Metge 2004). He taatairanga hoki ki tea o o te whenua taawhiti, te tai taawhiti raanei I nga pikitia peenaa I taa Vincent Ward, Ko Rain of the Children (2008), me taa Taika Waititi, ko Boy (2009)

This raises the question of near and far, an important distinction in Treaty settlements as the distant seas and the hinterland seem more easily settled or explored for minerals like oil and mined (Cleave2009). The distance between the urban nightmare described in Cat Ruka's and the rural life, or the distant warzone is important andseveral people have written about it. Work in tekaharoa.com by Paul Moon and Pare Keiha (Keiha and Moon 2008) is perhaps the most recent but there is a line of thought going back through Laurence McDonald's (1995 ibid) consideration of gender in Once were warriors. Beth likes the rural and Jake cannot relate to it. One thinks of Anne Salmond's discussion of rural capitals like Te Teko and Ruatoki Salmond 1975) or Joan Metge's discussion of the urban migration (Metge 2004). There are also correspondences to the rural life evoked in films like Vincent Ward's Rain of the Children (2008) and Taika Waititi's Boy (2009).

Mai i te whakaaturanga o Whakairo o te tau 2007 ka puta mai Te Whenua me te mahi kanikani naa Moss Paterson me te Kamupene Kanikani o Atamira. Mai i teenei whakaaturanga ka puta te aahua o te wairua me eenaa moumou mea ki a Te Koowhiti, aa, ka honoa te hohonu o te waa o neheraa o te Maori ki a Matariki ki Te Papa Tongarewa i te tau 2010. 


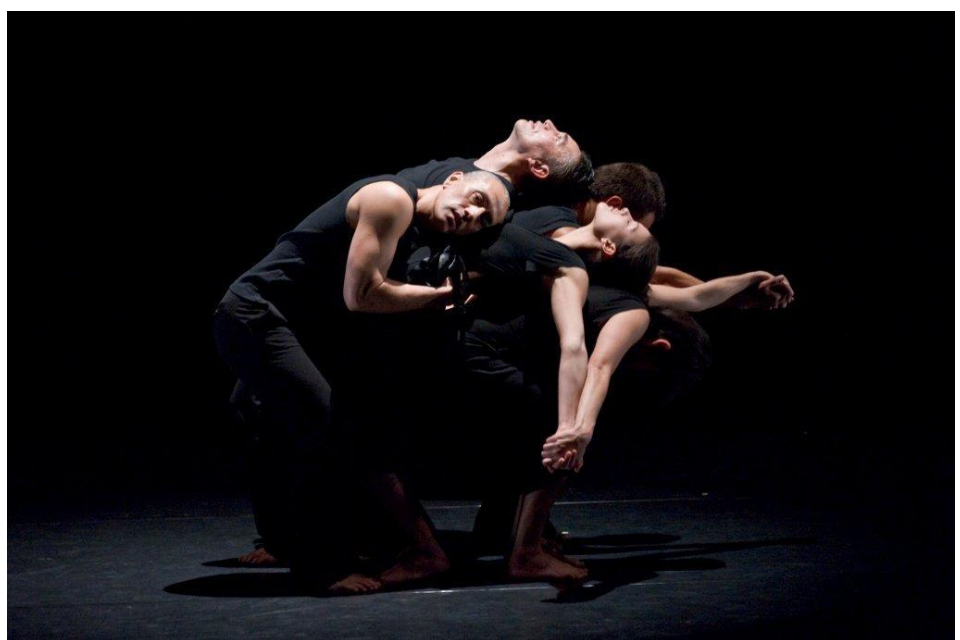

Atamira Dance Collective Maaka Peepene Choreographer

Te Whenua with choreography by Moss Paterson and the Atamira Dance Company came from Whakairo of 2007. This gave Koowhitia spiritual and mystic dimension and so connected the deep past of the Maori to Te Papa Tongarewa during Te Matariki of 2010.

Ko eetahi o nga mahi ka haere whakamuri, ka kookiri ki kookiri ki mua hoki. Mai i te Waa Piki o te tau 2009 moo te New Zealand School of Dance kua puta mai $\mathrm{He}$ taonga, he whakaaturanga me te mahere kanikani naa Taane Mete raaua ko Taiaroa Royal me te Okareka Dance Company. Ko teenei mahi hoohonu ka whakaroangia moo teetahi whakaaturanga i 2011. 


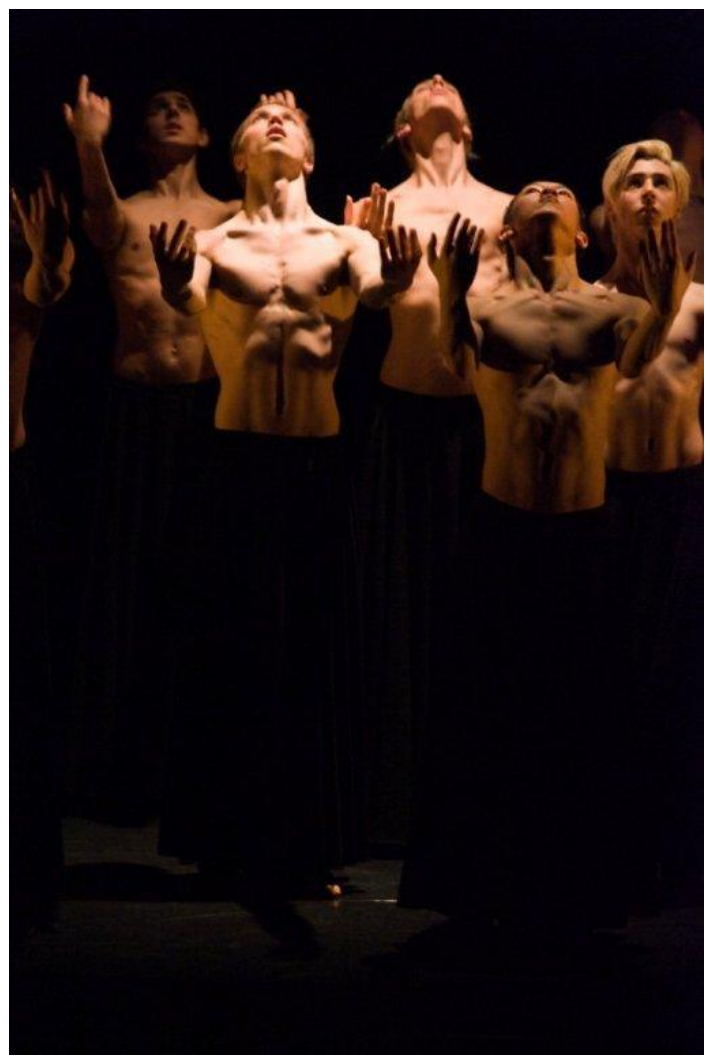

Okareka Dance Company - He Taonga

Some of the work went back as it projected forward. He Taonga with choreography from Taane Mete and Taiaroa Royal and the Okareka Dance Company came from a Graduation ceremony for the New Zealand School of Dance season in 2009 . This interesting work is being extended for a production in 2011.

Aa, ko teenei te aahua o te whakaaturanga. Ka titiro ki mua, ki muri hoki, kaaore kau he whakamau kaati, kaore he mauhere, kaore he taiapa kia aukatihia ngaa taangata. Aa, ka haangai a Koowhiti ki te waa o naaianei. ka mahia te mahi i te waa o inaaiatonurawaatunei, aa, ka toia te 
minenga ki teetahi aahua o naaianei e ia whakaaturanga, ia whakaaturanga.

And this was the way of the show. It looked forward as well as to the past with no holds barred, no prisoners taken and no boundaries to hem people in. And Koowhiti was made for the present. It worked in the here and now, each dance show tugging at the audience with another immediacy.

He mea nui te whakatakotoranga o te wa o naaianei $i$ mua tonu $i$ te minenga. Peenaa pea $i$ te rerekeehanga $o$ tata-taawhiti i meatia $i$ mua $i$ eetahi waa he taawhiti rawa te titiro ki nga aahuatanga o te Maaori. $E$ ai ki teenei titiro, i nga wai tino pai o neheraa he mea rangatira ngaa taangata i ora ai. Engari i Koowhiti ka kitea te pai o te ao Maori i teenei waa tonu. Kia whakaarongia te waa me te waahi ( cf Neocosmos 2006) he tika te kauwhata o te hinengaro, me kii, o Koowhiti.

This placing of the moment before the audience is important. Rather like the near-far space distinction so there is sometimes a distancing in time. Issues are approached from a way in time. According to this view once upon a time people were noble. But in Koowhiti the value of the Maori world today is to be seen. If time and place are considered (Neocosmos, 2006) it might be said that there is a true frame of mind in Koowhiti.

Ko te tuumanako kia mahi tahi anoo ai te tokoturu nei, ko Taanemahuta raatou ko Merenia ko Jenny. He pai eenei taangata hei mea takitahi; ko Taanemahuta ka whai taha ia, ko Merenia he puu whakahaere ia $i$ a ia e toro atu ana ki te ao toi, te ao pukapuka hoki, a, ko Jenny ka tautoko, ka ako ia. Hei roopu, hei takitoru me kii, he rawe hoki raatou.

It is to be hoped that this trio, Tanemahuta and Merenia Gray and Jenny Stevenson work together again. They are good enough as individuals; Tanemahuta pushing the envelope, Merenia creatively organizing as she reaches out to 
art and literature and Jenny advising and teaching. Put together they appeal immensely.

A, ka piikau taumaha raatou.

And they carry weight.

Ka hari a Taanemahuata me Merenia i te whaanau, aa, he whaanau anoo raa teenaa. He hononga kanikani e toro atu ki te ao kia hoki ai ki a Kaapiti. Ko Taanemahuta, kua hoki noa mai i taana mahi moo te New Zealand Expo ki Haina. Kua taea e raatou ko Merenia ko Jenny te kohinga kaikanikani rerekee engari raa kaaore he raruraru teenaa inahoki ka rere reka raa te whakaaturanga kaaore he amuamu $i$ te haerenga- kiihai te tangata $i$ moohio tuuturu he aha te mea e whai ai engari he ngaawari kau noa teenaa, ko teenaa te aahua o te koowhitiwhiti, te aahua tapere o te waihiirere.

Tanemahuta and Merenia bring the whanau and what a whanau it is. There are dance connections stretching out into the world and back to the Kapiti coast. Tanemahuata had recently returned from his involvement with the New Zealand Expo in China. He and Merenia had managed with Jenny to get many dancers of different types together but the show hummed rather than grated- you weren't sure what kind of dance you would see next and that was of no bother, it was the way of the koowhitiwhiti, the way the fountain played.

Aa, ka haria mai e Jenny Stevenson toona hoa rangatira ko Jim ki a Koowhiti. Ka koorerotia a Jim i te panui moo Koowhiti, he kaitautoko huumarie ia, he pou wahanguu moo te ao toi tae rawa anoo raa ki te kanikani ki Te Whanganui a Tara, he mea moohio ki te tautoko pai, aa, ki te hiikoi pai hoki.

And Jenny Stevenson brought her husband Jim to Koowhiti. Jim is mentioned in the Koowhiti Programme, he is a quiet mentor, a restrained consigliere of the arts, especially dance in Wellington, a patron who knows how to do it well and walk softly. 
Ko ia whakaaturanga he rapunga, aa, ko Taanemahuta tonu e tuuwhera kuuaha ana, e hoki ana ia $i$ taana mahi $i$ te taha o Jackie Chan ki Shanghai, kua heke a Taanemahuta i nga rangi moo teenei poo, e tiaki, tautoko hoki ia i nga kaikanikani, ka whakahaapai $i$ teenaa mea $i$ teenaa $i$ te tauira o toona anoo tinana. Aa, ko teenaa te aahua o te poo; ka arongia oo raatou tinana e nga kaiwhakaatu hei mea koorero. Ko teenaa teetahi o nga tino whakatuuwheratanga, puaawaitanga whakaaro me kii, e kitea nei e au i te nuku o te ao. I reira a Merenia puta noa hei mea whakamarino $i$ te wai, aa, $i$ ia kokona, ia kokona ko Jenny Stevenson, he hinengaro kanikani toona.

Each piece was an exploration with Tanemahuta Gray himself pulling out the stops, pulling back from working with Jackie Chan at the Shanghai Expo and down from aerial stuff for the night, mentoring, talking up things with his body. And that was the way of the night; all performers used their bodies to say something. It was the most open expression I've seen for a while, anywhere in the world. Merenia was there throughout, smoothing out the wrinkles and in every corner there was Jenny Stevenson, a mind of dance.

Ki tua o teenaa ko te hoatuhanga tohu. Moo te mahi e haangai, hookai raanei ki te kanikani Maaori o naaianei i te katoa o te oranga tangata eenei. I teenei waa $i$ kitea ai eenei oranga. Ko Gaylene Sciascia raatou ko Tama Huata ko Stephen Bradshaw nga pou o te ao kanikani mai raanoo. Ka hoatungia eenei tohu e nga taangata rongonui peenaa $i$ te Koromatua o Te Whaanganui a Tara me Gregory Fortuin mai i te Kaunihera o Whitireia, he kaitakawaaenga aa iwi o mua. Ka whakauruhia eenei e Brendon Pongia, he mea hoou rawa i nga waa katoa koia tonu raa teetahi $o$ te raarangi hirahira $o$ nga taangata rongonui i mene ai.

And then it was on to the presentation of awards. These were for contributions over a lifetime to Maori contemporary dance. And here the lifetimes were shown. Gaylene Sciascia, 
Tama Huata, Stephen Bradshaw, figures of a lifetime in dance. The awards were presented by the dignitaries; the Mayor of Wellington and Gregory Fortuin of the Whitireia Council and ex Race Relations Conciliator. All introduced by the indefatigably fresh Brendon Pongia, himself one of a formidable range of Maori dignitaries in attendance.

I te tau $1977 \mathrm{ki}$ te marae o Rongomaraeroa $\mathrm{i}$ Poorangahau ka puta mai a Gaylene Sciascia i teetahi hui kanikani Maaori. I toona waa oranga kua tiimatahia e ia eetahi waa ako kanikani i nga waahi peenaa i a Whitireia, aa, i mahere kanikanitia a Moko e ia, a, ka haria teenaa ki Haina me te New Zealand Ballet Company, aa, ko taana inaaianei kei te aarahi ia i teetahi roopu kanikani ki Croatia, Slovenia me Germany.

In 1977 at Rongomaraeroa marae at Porangahau Gaylene Sciascia was part of a hui for Maori dancers. In Gaylene Sciascia's lifetime of contribution dance courses have been started at places like Whitireia, a production called Moko was choreographed by her and then taken to China with the New Zealand Ballet Company and she is presently taking a dance group on a tour of Croatia, Slovenia and Germany.

Mai i te tau 1983 he rahi kee nga mea i hoatu i a Tama Huata ki te ao kanikani Maaori o teenei wa, aa, he hononga nui ki te ao kapa haka me nga kanikani Maaori o neheraa i toona nohohanga hei kaihautu o Te Matatini, te ahurei nui rawa $i$ Aotearoa nei. Ko teenaa te kaiwhakatiimata me te CEO o Kahurangi Maori Dance Theatre. Kei teenei he kaikanikani ruatekaumarua, he mahi tuuturu taa raatou, aa, e toru nga roopu e taiawhiao naa. Kua hari a Tama $i$ te kanikani Maori ki te ao whaanui tae rawa atu ki Amerika ki te tokerau.

From 1983 Tama Huata has contributed in many ways to Maori Contemporary dance and with his role as Chairman of Te Matatini, New Zealand's largest performing arts festival, there is an important connection to kapa haka and traditional Maori dance. He is the founder and CEO of Kahurangi Maori 
Dance Theatre. This has 24 full-time dancers in three troupes that tour internationally. He has taken Maori dance to the world especially to North America.

Ko te mea tuatoru ko Stephen Bradshaw, kua taahuritia ia i te ao o te kanikani Maori mai i te tau 1984. Ko toona haerenga he rerenga $i$ nga waa ako kanikani $i$ te tari whai mahi i 1984 ki te whakatuuranga o Taiao i 1988, ki te whakahaerehanga o teetahi hui taumata moo te kanikani Maaori i teenei waa i 2009. Ko teenei hui taumata te mea karanga mai $i$ te maheretanga moo Koowhiti Matariki Festival of Maori Contemporary Dance $i$ 2010.

The third contributor, Stephen Bradshaw has moved and shaken the world of contemporary Maori Dance since 1984. His journey has taken him from labour department employment schemes involving dance in 1984 to the formation of Taiao in 1988 to the convening of a summit on contemporary Maori Dance in 2009. This summit ushered in the planning process for Kowhiti Matariki Festival of Māori Contemporary Dance in 2010.

Ko nga tohu tonu, ka haramai eenaa hari koorero ana. Kua whakairongia a Charles Koroneho he kii, he mea tuuwhera hoki, aa, ko nga whakaaturanga o eenei he wahanga o nga hoatuhanga tohu. Ko teenei teetahi anoo aahua kotiti o Koowhiti, teetahi anoo mahi whakangaahau, whakamoohio hoki ki te whakamau tonu rawa $i$ ngaa whakaaro o te minenga. Ko te whakaaro whakairo o Toki Pitangata; lock and key ka utua teenaa e Creative New Zealand, ka haria te toi whakairo ki a Koowhiti i too Charles Konehoneho whakaaro moo ngaa kii kia whakatuuwheratia nga whakairo i whakakamaaramatia i whakaatuuhia hoki i runga ahurewa. Ka meatia teenei i te paanui peenei;

The awards themselves came with interesting stories. Charles Koroneho had carved keys and locks and these were displayed as part of the presentations. This was yet another 
twist to Koowhiti, another way of entertaining and holding the attention right up there. The design concept of Toki Poutangata; lock and key was paid for by Creative New Zealand and brought sculpture to Koowhiti as Charles Koroneho's idea of keys to unlock the carvings were explored and shown on stage. This is all described in the handouts as;

Embodying the mana of the awards is the Toki; symbolically representing a body, a form of technical potential and precision, an expression of the highest commitment to knowledge, culture and artistic excellence. The Toki is therefore a material depiction of Maori Dance; the history, creative aspirations and cultural foundation that practitioners are collectively working to unlock.

The concept of Poutangata is metaphorically represented by the Awards Recipient, an individual celebrated for their pursuit of excellence and unlocking the full potential of Maori Dance and Performance. Their contribution and lifelong commitment is literally cut from the body of the adze and transformed into a symbolic key, an anthropomorphic manifestation.

Kanikani. Waa oranga. Whakaaro whakairo. Kia whakatuu whakangahau a Jenny Stevenson raatou ko Merenia ko Taanemahuta Gray tirohia nga mea e taea me nga taangata e puta!

Dance. Lifetimes. Design Concepts. When Jenny Stevenson and Tanemahuta and Merenia Gray throw a party look at what happens as well as who turns up!

I mua i te titiro anoo ko wai i puta ai e tika ana pea kia whakaarongia ko wai kaaore i puta mai. He aahua rerekee te putahanga mai o ngaa mea mai i te ao paaho, ko au mai i a a Kia Ora FM, Papaioia, he kaiwhakaahua hoki mai i te Dominion Post. Kiihai au i kite $i$ eetahi atu mai i teenaa teihana reo irirangi peenaa, me kii, $i$ te New Zealand Listener, Te Pouwhakaata Maori, Pouwhakaatu Tahi, Rua, Toru raanei, a, he mea rerekee teenei kia whakaarongia ai 
te pai noa o te mahi e kitea, rongohia hoki me te aronga o teenei moo te motu whaanui.

Before looking again at who showed up it was interesting who was not there. There was an uneven media presence with myself from Kia Ora FM, Palmerston North and a photographer from the Dominion-Post. I did not see anyone else from any other radio stations including National Radio or from other media like, say, The New Zealand Listener or Maori Television, TV One or Three and this is remarkable given the sheer quality of the visual and aural work and its national significance.

Ko Fortuin te tino kaikoorero o te poo naa te mea pea ka piri ia $i$ te nako o te kaupapa moo te motu whaanui $i$ Koowhiti. He tangata mai i a Awherika ki te Tonga paku moohio ki te koorero Maaori, ka mau ia $i$ te hirahira o te waa moo te kanikani mai i teenaa kokona, teenaa., aa, ka koorero atu ia i teenaa. Pai rawa ia ki a maatou mai i a Aotearoa tae noa ki nga mea rongonui e noho aahua wahanguu ana!

Fortuin was the most loquacious speaker of the night and this was, I think, because he grasped the nettle of national significance in Koowhiti. A Maori speaking South African, as well as grasping it he really articulated the shared pride in the dance from all quarters rather than knowing what we all mean as per the rest of the Kiwi Digs.

I a Gregory Fortuin e koorero ana ka hoki tooku mahara ki taa Bernard Levin moo Kiri Te Kanawa $i$ te niupepa e kiia nei ko te Times of London, te tangata tautoko rawa e haapai ana $i$ te whetu ki te tihi tiiahoaho ai. He mea pai pea kia tuhi peenaa ai a Gregory $i$ te Dompost! Kia waihongia eenei mea poka noa ki te taha kaaore kau he paatai he whakaaturanga teenei e piirangitia mai $i$ runga e nga mema paremata, te Koromatua me taana Aapiha Tautoko, he mea i piirangitia raa hei tihi moo Matariki, piirangitia hei waa whakakotahi i a taatou. Ka puta ki te taringa, ki te hinengaro hoki te 
koohumuhumu moo teetahi waa whakataa moo te motu i te waa o Matariki.

Gregory Fortuin talking about Koowhiti reminded me of Bernard Levin in the Times of London writing about Kiri Te Kanawa, the gusher helping to push the star to shining point. A pity Gregory does not have a column in the Dompost.!These curiosities and speculations aside there is no question that it was a show wanted on high, wanted by the parliamentarians, the High Court Judges and the Mayor and her Deputy, wanted as a point in Matariki, wanted for a shared celebration. The murmur of a national holiday to celebrate Te Matariki came to ear and mind.

I te tino pai o te whakaaturanga me te kiikii hoki o te hooro e tika ana pea kia whakaputa ai ki te taha o teenei mea te paatai moo te itiiti o ngaa kaitautoko. Ka puta mai a Mobil Oil, a Benson and Hedges me eetahi poutautoko peenaa i a Covent Garden, a Norman Kirk me Tiaare, HRH, hei hoa tautoko i a Kiri Te Kanawa. He ao iti rawa te ao toi i teenaa waa ki teenei inahoki kaaore kau he ipurangi noo reira he ngaawari atu pea te mahi tautoko $i$ teenaa waa. Kei hea te tautoko mai $i$ te ao kamupene me te Kawanatanga moo te whakaaturanga peenaa i a Koowhiti? Kaaore kau $i$ te pai maa Jim Stevenson me ngaa taangata o Te Papa Tongarewa e karanga atu ki te ao whaanui, a, kia toro kamakama atu ai hoki a Jenny raatou ko Taanemahuta ko Merenia ki nga mea moohio i a raatou kia taea ai te mahi.

With a quality performance and a sold out attendance the question of publicity and promotion might be put alongside another question about the lack of a substantial sponsor. Kiri Te Kanawa had Mobil Oil, Benson and Hedges and a mix of Covent Garden, Norman Kirk and, of all people Prince Charles behind her. And the world of entertainment and art was a smaller place without the internet so these things were more easily patronized and sponsored. Where is the support from corporate and government for a show like Koowhiti? It is simply not enough to have Jim Stevenson and the events 
people from Te Papa rallying the troops in support with Jenny, Tanemahuta and Merenia and all networking furiously to make things happen.

Atu i te pai me te kaha o te whakaaturanga he paatai nui e puta moo te katoa o Koowhiti tae noa mai ki eenaa $i$ hoko tikiti ai moo te haakari, aa, ka puta hoki maatakitaki noa ai. Ko teenei teetahi o nga paatai e haangai ana ki te reanga o te toi, he mea whakarunga, he mea whakararo raanei, he mea whakakaati pea peenaa i te kuuaha hinengaro pea. I teenei pito me kii, ko Dancing with the stars, aa, i teenaa pito ko te mahi naa te New Zealand Ballet Co pea. Kei teenaa kokona ko Kapa Haka, kei teeraa kokona ko Koowhiti.

Aside from the quality and power of the performance the whole event including those who bought tickets to the dinner and showed up to watch poses some pretty big questions. There is something of a brow problem as in high or low brow, or something of a block problem as in a mental block with all of this. Dancing with the stars is at one end of a spectrum while the work of the New Zealand Ballet Company is at another. Kapa Haka is in one corner and works like $\mathrm{Te}$ Koowhiti are in another.

Ko teenei rerekeehanga, teenei whakakaatihanga, kaaore teenei e paa atu ki nga mea e kanikani tonu ana wheenaa i a Jenny, Taanemahuta, Merenia me aa raatou kaikanikani. Engari e haangai ana teenei ki nga mea e maatakitaki ana pea. Nga mea kaaore e maatakitaki ana raanei. Ki a au noa ko te aahua o teenei minenga, he rerekee ki teenaa e kitea nei i ngaa ahurei kapa haka. Ki a au tonu nei kaaore te raarangi o ngaa taangata wheenaa $i$ too te Koowhiti e kitea $i$ nga ahurei o te New Zealand Ballet Company.

This difference of brows, this blockage, does not seem to apply to the people deeply involved in dance such as Tanemahuta, Merenia or Jenny or any of their dancers, But it might apply to those watching. Or not watching. The kind of 
turnout of Digs, Maori and Pakeha Dignitaries, at Koowhiti is not seen, at least in my experience, at Kapa Haka festivals. Nor, again in my experience at least, is the range of people attending Kowhiti seen at New Zealand Ballet performances.

Ka noho tonu te paatai; he aha kee teenei? Kanikani Maaori mai i te ao hoou? Kapa Haka? Ballet Maaori? Burlesque Maaori? Ka taea nga mea katoa, aa, ka pikia nga tihi teitei, hei tauira te pai o taa Cat Ruka. He rerekee anoo teenei $i$ aa Taa Apirana Ngata $i$ muri $i$ te Pakanga Tuatahi i a ia e karanga atu ki te iwi kia uru ai raatou ki te mahi waiata aa ringa kia whakahaapaingia te mahi ahurei me te koorero me te waiata $i$ te reo Maaori. Kaaore he rahi te tuhituhi moo teenei take, aa, ka hoki te tangata ki te pukapuka pai naa Jennifer Shennan, The Maori Action Song i whakataa ai i NZCER i te tau 1984.

There is, of course the question; what exactly is this? Modern Maori Dance? Kapa Haka? Maori Ballet? Maori Burlesque? Anything goes and to great effect as in the case of Cat Ruka. Koowhiti may not have been what Sir Apirana Ngata had in mind after the First World War when he encouraged people to join concert parties as part of an attempt to foster Maori performance that itself encouraged people to speak and sing Maori. Nor is it something greatly written about and one goes back to Jennifer Shennan's good book, The Maori Action Song published by the NZCER in 1984 for a steer on the subject.

E tika ana pea kia uia ai te paatai moo te aro o te kanikani ki te motu whaanui. $E$ taea te oritenga $O$ te aronga o te Ballet ki nga mea o Ruhia me te Haka ki nga mea o Aotearoa/ Niu Tiireni? E hia nga haka e kitea i nga Commonwealth Games? Mai $i$ teenei tirohanga ko koowhiti he whakatuuwheratanga o oo taatou ngakau i a taatou, kia whakahokia ai taatou ki te waa o naaiatonurawaatuneinaa.

It seems worth exploring the idea that dance might mean something for nation. Can we compare Ballet to Russians to 
haka to New Zealanders? How many haka are to ne seen at the Commonwealth Games? Considered from this perspective, Koowhiti was a way of unlocking our myths, of bringing us to the moment of ourselves.

I te taha o teenei ko nga paatai e taatai ki noo wai raanei nga aahuatanga $o$ te haka. $E$ uia pea noo wai te whare o te kanikani Maaori (Brown 2003, Goldsmith 2009)

Along with this come matters of ownership and appropriation regarding the haka. It could be asked who owns the house of Maori dance (cf Brown 2003, Flavell 2010, Goldsmith 2009)

Hei aha raa, ko Koowhiti, te taperehanga o te maarama i te kanikani, kei koonei maa taatou e kite, aa, he mea whakakuukune whakaaro. He mea hoou maa taatou e moohio, wheenaa i te motu tonu, Aotearoa/Niu Tiireni.

But whatever Koowhiti, the play of light in dance, is, it is ours to see, it is here and it is exciting. There is innocence about it all for us to experience like the country Aotearoa/New Zealand itself.

Kia hoki ai taatou ki te mahi i kore i taea ai e te ao paaho moo teetahi mea peenei i puta i Te Papa Tongarewa, e ai ki te whakaaro he kaatihanga kee teenaa. He peenaa $i$ teetahi mea huna a Koowhiti, teetahi mea maa nga mea moohio e whai engari kau ra he kaatihanga kee e puta i te hinengaro o eetahi peenaa $i$ nga mea $i$ te ao paho me te ao tautoko hoki...

Coming back to the patchy media coverage of something held at the national museum a block for work like Koowhiti seems to exist in the media though. It is as though Koowhiti is a secret, something for a cognoscenti with blocks for others in the silliest of places; media and sponsorship... 
Engari raa kia tirohia teenei mai $i$ te whakaaro o te motu he putahanga taangata pai i Koowhiti, he pikitia teenei e whakahoki ana $i$ a taatou ki te paatai ko wai kee tatou. Ko ngaa mea peenaa i a Fortuin, i a Prendergast hoki, nga mea aarahi whakaaro moo te haapori whaanui, he mea ngaawari rawa a Koowhiti ki a raatou. Ka puea ake te paatai moo taatou o te motu; kua whakaatu mai a Koowhiti i teetahi mea maa taatou katoa e pai noa atu? He peeraa pea, ki te hoki anoo raa ki a ia, i a Kiri Te Kanawa i nga mea i kiia ai nga Mobil Song Quests $i$ te tekau tau atu i 1960. Ko te whakaaro $i$ haria atu ai e nga Fortuins, nga Prendergasts hoki ko Koowhiti he mea pai kia kaitahitia ai e taatou, hei mea tuu hirahira maa taatou. Ka whakaae au.

But looking at it from a national or even a nationalistic basis there was a significant and telling presence, a social and political representation of who we are at Koowhiti. People like Fortuin and Prendergast, people who eventually lead opinion are exceedingly comfortable with the work as presented at Koowhiti. The question of shared national experience of the arts arises; has Koowhiti offered us something that we can all share in an unabashed way? Like, to refer to her again, Kiri Te Kanawa at the Mobil Song Quests in the sixties. The idea taken by the Prendergasts and Fortuins was that Koowhiti was something that might be shared and valued by all of us. I agree.

Ko eenei nga mea $i$ taea ai e au i te waa o Matariki. He aha te aha moo teenei?

So these were the kinds of things that I did during Matariki. What is to be made of it all?

I eetahi waa ka puta te whakaaro he rahi nga aahua o Matariki- kia whakaaarongia ai ngaa waa whakaraarangi ahurei wheenaa $i$ te Kirimete me nga mea $o$ te ao kamupene, te ao Paakehaa me kii- he kauwhata ki raro o Matariki, aa, maa teenaa roopu, teenaa e whakatakoto tohu, whakatuu $i$ oo raatou anoo aahua $i$ runga $o$ teenaa 
kauwhata. He mea katakata, he mea taumaha, he mea tapere noa raanei $i$ a Matariki.

While it sometimes seems as though there are many shapes to Matariki- compared say to the tight packaging of Christmas and the commercially driven festivals and celebrations of the West ar least- there is an underlying structure upon which groups can put their own mark, make their own configurations. There is seriousness and there is humour, there is play.

Kei te koorero ki runga ka kitea eetahi kauwhata whakaaro e rua moo Matariki; te mahi i meatia ai e Rangitaane o Manawatu i te mea e kiia nei e raatou ko te Tau Hoou Maori me te mahi i ahureitia ai i Te Papa Tongarewa. He rerekee ano te wiri me te rongo o teenaa mahi Matariki, teenaa raanei; ka whai eetahi aahua pea $i$ eetahi anoo. I ia moumou Matariki ka kitea te tapere aa hinengaro, te tapere aa haapori raanei (Moreno 1947 Holmes 1992).

The discussion above talks about two such configurations; the Rangitaane o Manawatu way of doing things at the Maori New Year as it is called there and the way Matariki was celebrated at Te Papa Tongarewa. Different shapes resonate in different ways; some shapes might seem to echo others. There are elements of psychodrama or sociodrama in each configuration, ways of working out the way forward (Moreno 1947 Holmes 1992).

Hei tauira ko te ahurei o nga Tuahine Tokowhitu ki Te Papa, ka whai teenaa $i$ te whakaaro Kiriki mo nga Tuahine Tokowhitu i nga Pleiades, aa, ka whai pea te ahurei e kiia nei ko nga Tuakana Tokowhitu i te whakaaro o nga whetu e whitu me nga Tuahine Tokowhitu. Teeraa pea ka whai eenei waa tapere $i$ eetahi whakaaro Maaori moo Matariki.

For example the Seven Sisters concert at Te Papa may echo the Greek idea of Seven Sisters in the Pleiades while the Seven Brothers concert at Te Papa may echo both the idea of 
seven stars and mirror the Seven Sisters performance. Or perhaps these performances follow some other Maori ideas about Matariki.

Ehara kau i te mea he waa uu, he waa rapu kee a Matariki. Ko te tipuranga o Matariki I te tekau tau I mahue noahe maranga hoou, he mea e hari mai ana I teetahi moohiotanga kaaore anoo ia tau noa. Ka whakaaro te tangata moo eetahi tuhinga moo tea $o$ hoou e whakaarongia moo te Maaori (cf Moon 2008). He ao hoou anoo teenei? Tera pea he huarahi whakaaro moo ngaa taangata tata mai kia whakataetaetia anootia ngaa aahua o te roopu (Bion 1955, 1961)? He huarahi whakaaro raanei kia moohio ai taatou ko wai kee taatou (Cummins 1996)?

Rather than Matariki being a fixed experience it is a time of exploration. Is the growth in interest in Matariki over the last decade part of a new awakening, something that is bringing awareness but has not so far settled down? One thinks of recent writing on supposed Maori renaissances (cf Moon, $P$ 2008). Is this another renaissance? Or is it a way of relating to those around you, an exercise in evaluating group dynamics (Bion 1955, 1961)? That is true of the Rangitaane Paa experience discussed above. Is it a way of negotiating identity (Cummins 1996)?

Maa teenaa, teenaa raanei e whiriwhiri i taana e pai ai moo Matariki. He whiringa, he raarangi whiringa me kii, o nga pakitara maana, maa raatou raanei e whai. He mea orite pea ki teenaa ko te huarahi whiriwhiri maa teenaa, teenaa raanei moo te waa me te waahi. Ko teenei tonu he mea whakataa engari raa $i$ eetahi waa ka koorero te tangata i oona anoo raa aro, wawata, tuumanako hoki $i$ te waa o Marariki. I ia rohe, ia rohe o te motu kua taea he rapunga $i$ te kitenga anoo o Matariki i eenei tau tekau, rua tekau raanei i mahue noa. I eetahi waa he whawhai teenei, aa, ka whakaarongia anootia te whawhai naa Tania Ka'ai kia whakatuungia he marae, he waahi Maori raanei $i$ teetahi whare waananga (Ka'ai 2008). Mai i teetahi anoo 
titiro he mea tuuwhera a Matariki i te puu tapere (Cleave 2009b).

One can choose, in effect, what kind of Matariki one wants. There is a choice, a smorgasbord even, of myths to experience. As or more important there is the possibility for people to choose a time and space. This is in itself a statement but sometimes as with the Rauna Tapu in Tuturu Pumau there is the chance for the person to make a statement about their feelings, hopes and desires at the time of Matariki. In each area of the country there has been an exploratory process over the last ten or twenty years as Matariki has been rediscovered. Sometimes this has been a struggle and one thinks of Tania Ka'ai's struggle to establish a marae or a Maori space in a university (Ka'ai 2008). From another perspective Matariki taps an impulse to perform (Cleave 2009b).

Ko te waa o Matariki he waa, he waahi hoki maahau e kii he aha taahau naa piirangi $i$ te tau e tuu nei, aa, koo teenei teetahi o ngaa aahua o te Rauna Tapu o ngaa korero i te wharenui o Tuuturu Puumau ki Rangitaane Paa. He waa maa teenaaa, teenaa raanei $e$ whakatakoto $i$ oona anoo wawata moo te tau hou. Wheenaa raa pea ngaa ahurei i meatia ai ki runga inahoki kei reira hoki te whakaatuuranga o ngaa wawata, moemoeaa hoki. Ko Ria Hall he tangata tuu kaha ake, tuu whakahirahira hoki moo oona piiranga maa te iwi Maaori tae rawa ki nga waahine Maaori. Aa, ko Cat Ruka, he mea maarama ki te minenga taana moo nga mea kaaore e piirangitia e ia i taana mahi porotete. Kia whakaarongia a Koowhiti hei mea kotahi e titiro whakamua, he tino titiro i a Merenia raatou ko Taanemahuta ko Jenny Stevenson. Ko taaku Matariki, he mea pai moo te whai whakaaro, he atamira pai moo te waananga hei mea awhi hinengaro, hei mea whakahaapai mahi.

Matariki offers a time and place for saying what you want in the new year and this is one of the functions of the Rauna Tapu of speeches in the wharenui at Tuuturu Puumau, Rangitaane Paa. People have a chance to set out their hopes 
for the new year. Similarly the performances discussed above offer hopes and dreams. Ria Hall was emphatic and inspirational in her performance about what she wanted for Maori, especially Maori women. And of course so was Cat Ruka in her dance threatre work which told the audience what she did not want in her piece of protest. Koowhiti as a whole could be seen as a look forward with some coherence by Merenia and Tanemahuta Gray and Jenny Stevenson. The whole experience of Matariki worked for me as a reflective device, a heuristic whereby I was helped to reflect upon and try to improve upon experience. 


\section{Bibliography}

Best, Elsdon The astronomical knowledge of the Maori. Wellington: Government Printer, 1986

Bion, W R 1955, Group dynamics- a review, In S Scheidlinger (Ed) Psychoanalytic Group Dynamics- Basic Readings. New York: IUP

Bion,W. R. 1961 Experiences in Groups and other papers, Routledge, London.

Boal, Augusto 1995 The Rainbow of Desire Routledge, London

Brown, Michael F. 2003. Who Owns Native Culture? Cambridge: Harvard University Press,

Cleave, P 2009a Starting Points Campus Press

Cleave, P 2009b Te Pu Tapere, the impulse to perform, Campus Press

Cummins J 1996 Negotiating Identities; education for empowerment in a diverse society Ontario: Canadian Association for Bilingual Education

Flavell, Te Ururoa, Speech to Tapu Te Ranga marae, 2010

Goldsmith, M. 2009 Who owns native nature? Discourses of rights to land, culture, and knowledge in New Zealand. International Journal of Cultural Property, 16, 325-339.

Holmes, Paul 1992 The inner world outside; Object Relations, Theory and Psychodrama Tavistock/Routledge London and New York

Ka'ai. Tania, 2008, The Role of Marae in Tertiary Education Institutions Vol 1 tekaharoa.com

Ka'ai Mahuta, Rachel Te Awhina, 2009 The Impact of Language Loss on the

Maori Performing Arts Mahuta Ka'ai).

http://web.mac.com/tekaharoa/Site/Home_2_files/Microsoft\%20Wor d\%20-\%20Journal_1_8.pdf

Keiha, Pare and Moon, Paul 2008 The Emergence and Evolution of Urban Māori Authorities: A Response to Māori Urbanisation, tekaharoa.com Vol 1, No 1 pp1-17

McDonald, Laurence 1995 Film as a Battleground: Social space, gender conflict and other issues in Once Were Warriors. In Ilusions 24 Spring: 15-23

Metge, J 2004 A New Maori Migration: Urban and Rural Relations in Northern New Zealand, Berg

MEREDITH PAULHTTP://WWW.TEARA.GOVT.NZ/EN/MATARIKI-MAORI-NEWYEAR/ 1

http://www.korero.maori.nz/news/matariki

Moon, P 2008 A chequered Renaissance:The Evolution of Maori Society. www.tekaharoa.com Vol 2 Pp 23-41

Moreno, J L 1947 The Future of Man's World, New York Beacon House, Psychodrama Monographs

Neocosmos, Michael, 2006 From Foreign Natives to Native Foreigners: explaining xenophobia in contemporary South Africa, Dakar: Codesria

O'Regan H 2008 Toituu te iwi: A Journey in the Evolution of Cultural Identity, www.tekaharoa.com Vol 2 pp 77-88 
Salmond, Anne 1975 Hui, Reed, Auckland

Shennan, Jennifer, 1984, The Maori Action Song, New Zealand Council for Educational Research

Smith, Cheryl Te Waerea, 1993 'The natives are restless' in Murphy, T (ed). Treaty of Waitangi Flora and Fauna Claim (Wai 262). 